\title{
Continuous infusion of antibiotics in the critically ill: The new holy grail for beta-lactams and vancomycin?
}

\author{
Bruno Van Herendael ${ }^{1 *}$, Axel Jeurissen ${ }^{2}$, Paul M Tulkens ${ }^{3}$, Erika Vlieghe ${ }^{4,5}$, Walter Verbrugghe ${ }^{6}$, \\ Philippe $\mathrm{G}$ Jorens $^{6}$ and Margareta leven ${ }^{1}$
}

\begin{abstract}
The alarming global rise of antimicrobial resistance combined with the lack of new antimicrobial agents has led to a renewed interest in optimization of our current antibiotics. Continuous infusion (Cl) of time-dependent antibiotics has certain theoretical advantages toward efficacy based on pharmacokinetic/pharmacodynamic principles. We reviewed the available clinical studies concerning continuous infusion of beta-lactam antibiotics and vancomycin in critically ill patients. We conclude that $\mathrm{Cl}$ of beta-lactam antibiotics is not necessarily more advantageous for all patients. Continuous infusion is only likely to have clinical benefits in subpopulations of patients where intermittent infusion is unable to achieve an adequate time above the minimal inhibitory concentration (T > MIC). For example, in patients with infections caused by organisms with elevated MICs, patients with altered pharmacokinetics (such as the critically ill) and possibly also immunocompromised patients. For vancomycin $\mathrm{Cl}$ can be chosen, not always for better clinical efficacy, but because it is practical, cheaper, associated with less $\mathrm{AUC}_{24 \mathrm{~h}}$ (area under the curve $>24 \mathrm{~h}$ )-variability, and easier to monitor.
\end{abstract}

Keywords: Continuous infusion, Intermittent infusion, Vancomycin, Beta-lactam, Antibiotic(s), Critically ill, Pharmacokinetic/pharmacodynamic

\section{Background}

Antimicrobial resistance is emerging worldwide [1]. In addition there is a dramatic lack of new antimicrobial agents being explored in phase 2 or 3 clinical trials, especially for Gram-negative organisms, and development of an antimicrobial with a genuinely novel mechanism of action is estimated to take years [2].

These evolutions have spurred interest in maximizing the effectiveness of our current antimicrobial armamentarium to retain its activity for the years to come. One of the ways to achieve this is through optimization of antibiotic dosing regimens based on pharmacokinetic/pharmacodynamic (PK/PD) principles. Animal studies and PK/PD studies suggest that efficacy of beta-lactam antibiotics is better when administered as continuous infusion (CI) or prolonged infusion than when administered as intermittent infusion (II), yet this remains to be

\footnotetext{
* Correspondence: Bruno.van.herendael@uza.be

'Department of Microbiology, Antwerp University Hospital, Edegem, Belgium Full list of author information is available at the end of the article
}

proven in clinical outcome studies. CI of vancomycin also is increasingly popular, albeit more for practical reasons and aiming to limit toxicity rather than for reasons related to PK/PD and expected clinical efficacy. In this paper, we therefore focus on the clinical evidence for CI of both the beta-lactam antibiotics and vancomycin in critically ill patients.

\section{Review}

$\beta$-lactam antibiotics

Beta-lactam antibiotics are "time-dependent antibiotics". Their maximal killing rate is achieved at concentrations that are only about four times the minimal inhibitory concentration (MIC), which is a relatively low concentration if considering the actual serum levels that are achieved by intermittent administration (typical $\mathrm{C}_{\max }$ will reach values $>80 \mathrm{mg} / \mathrm{L}$ ), and the current clinical breakpoints of beta-lactams (i.e., the highest MIC that an antibiotic may show against a given organism while keeping a high likelihood of clinical success) that rarely 
exceed $16 \mathrm{mg} / \mathrm{L}$. Concentrations higher than four times the MIC do not lead to more bacterial killing [3-5]. For beta-lactam antibiotics, therefore, not the peak concentration (nor the area under the curve as such) correlates best with efficacy, but rather the fraction of the time during which the serum concentration of the antibiotic exceeds the MIC between two successive administrations (T $>$ MIC) $[3,6]$. For most non-life-threatening infections in nonimmunocompromised patients, a T $>$ MIC of 40$50 \%$ is sufficient for successful clinical outcome. Animal studies with Streptococcus pneumoniae infected nonneutropenic mice showed that survival reached a plateau (with excellent survival) if serum levels exceeded the MIC for no longer than $40-50 \%$ of the dosing interval (reviewed in [7]). A recent human study, however, suggests that for critically ill patients clinical outcome might be better if $\mathrm{T}>\mathrm{MIC}$ approximates the full $100 \%$ [8]. Although $\mathrm{T}>\mathrm{MIC}$ is the most important parameter it also is important to achieve a steady state concentration (Css) of at least 2.5 times the MIC and preferably 4 times the MIC. Mouton and Hollander [9] showed that a Css equal to or slightly above the MIC during continuous infusion can lead to selection of resistant subpopulations in vitro. In a study from Alou and coworkers [10], the authors advise a Css/MIC ratio of at least 2.5, because they found bacterial regrowth when the Css/MIC ratio was 1.26 , but not when it was 2.5 .

Several PK/PD studies with different beta-lactam antibiotics have shown that their administration by CI significantly increases the likelihood of maintaining serum levels above the MIC compared with II, most notably when considering the highest clinical susceptibility breakpoints [10-18]. This is well illustrated in study by Alou and coworkers [10] who used a pharmacokinetic computerized model to simulate concentrations of ceftazidime in human serum after administration of $6 \mathrm{~g} /$ day using either CI or II. Using isolates with MICs of 8, 16, and $32 \mathrm{mg} / \mathrm{L}$, the authors found a $\mathrm{T}>\mathrm{MIC}$ of $99.8 \%$, $69 \%$, and $47.6 \%$, respectively, for the bolus regimen and $100 \%$ for all strains with CI. Therefore, a first population at risk to consider for $\mathrm{CI}$ is patients with infections caused by pathogens with MICs close to the susceptibility breakpoint. A second at-risk population are critically ill patients where altered physiology with increased volume of distribution $\left(\mathrm{V}_{\mathrm{d}}\right)$ and increased drug clearance can lead to lower initial as well as faster decreasing serum concentrations than expected for typical drug dosages $[19,20]$. This adds a direct pharmacokinetic argument to the well-accepted necessity to ensure a longer $\mathrm{T}>\mathrm{MIC}$ in critically ill patients compared with other patients for pharmacodynamic reasons [8]. A third population at risk might be neutropenic patients. A series of animal studies [21-24] comparing clinical outcome after CI versus II in rats with pulmonary infection shows a clear benefit in neutropenic rats in favor of CI. The daily dose needed to protect $50 \%$ of the rats from mortality was 15 times lower with CI. This effect disappeared in nonneutropenic animals.

Patients in the ICU are at risk for infections with higher MICs. For these infections, it can be quite difficult to achieve acceptable PK/PD targets with classical intermittent dosing regimens. Even when using $\mathrm{CI}$, the

Table 1 Overview of studies investigating PK-parameters of continuous infusion of different antimicrobials in critically ill patients

\begin{tabular}{|c|c|c|c|c|c|c|c|}
\hline \multirow[t]{3}{*}{ Antibiotic } & \multirow{3}{*}{$\begin{array}{l}\text { Mean } \\
\text { Css } \\
(\mathrm{mg} / \mathrm{L})\end{array}$} & \multicolumn{4}{|c|}{ Enterobacteriaceae } & \multirow{2}{*}{\multicolumn{2}{|c|}{$\begin{array}{l}\text { Pseudomonas aeruginosa } \\
\text { EUCAST and CLSI }\end{array}$}} \\
\hline & & \multicolumn{2}{|l|}{ EUCAST } & \multicolumn{2}{|l|}{ CLSI } & & \\
\hline & & Breakpoint & $\begin{array}{l}\text { Ratio: Css/highest } \\
\text { possible MIC within } \\
\text { susceptibility range }\end{array}$ & Breakpoint & $\begin{array}{l}\text { Ratio: Css/highest } \\
\text { possible MIC within } \\
\text { susceptibility range }\end{array}$ & Breakpoint & $\begin{array}{l}\text { Ratio: Css/highest } \\
\text { possible MIC within } \\
\text { susceptibility range }\end{array}$ \\
\hline Ceftazidime [25]6 g/24 h & 75 & $\leq 1$ & 75 & $\leq 4$ & 18.75 & $\leq 8$ & 9.37 \\
\hline Ceftazidime [26]4.5 g/24 h & 47 & $\leq 1$ & 47 & $\leq 4$ & 11.75 & $\leq 8$ & 5.87 \\
\hline Ceftazidime [27]3 g/24 h & 30 & $\leq 1$ & 30 & $\leq 4$ & 7.5 & $\leq 8$ & 3.75 \\
\hline Ceftazidime [28]60 mg/kg/d & 19 & $\leq 1$ & 19 & $\leq 4$ & 4.75 & $\leq 8$ & 2.37 \\
\hline Ceftazidime [29]4 g/24 h & 40 & $\leq 1$ & 40 & $\leq 4$ & 10 & $\leq 8$ & 5 \\
\hline Ceftazidime [1 1]6 g/24 h & 63 & $\leq 1$ & 63 & $\leq 4$ & 15.75 & $\leq 8$ & 7.87 \\
\hline Cefepime $[30] 4 \mathrm{~g} / 24 \mathrm{~h}$ & 41 & $\leq 1$ & 41 & $\leq 8$ & 5.13 & $\leq 8$ & 5.13 \\
\hline Cefepime [31]4 g/24 h & 13.5 & $\leq 1$ & 13.5 & $\leq 8$ & 1.68 & $\leq 8$ & 1.68 \\
\hline Piperacillin [32]13.5 g/24 h & 35 & $\leq 8$ & 4.37 & $\leq 16$ & 2.18 & $\leq 16$ & 2.18 \\
\hline Piperacillin [33]12 g/24 h & 18 & $\leq 8$ & 2.25 & $\leq 16$ & 1.125 & $\leq 16$ & 1.125 \\
\hline Meropenem [15]3 g/24 h & 7 & $\leq 2$ & 3.5 & $\leq 1$ & 7 & $\leq 2$ & 3.5 \\
\hline
\end{tabular}


Table 2 Characteristics of studies comparing outcome for continuous versus intermittent administration of piperacillin

\begin{tabular}{|c|c|c|c|c|c|c|c|}
\hline Study & Drug & Patient population & Dosage & Study type & Outcome measure & Outcome & Remarks \\
\hline $\begin{array}{l}\text { Grant } 2002 \\
{[49]}\end{array}$ & Piperacillin-tazobactam & Hospitalized patients & $\begin{array}{l}12 \mathrm{~g} / \mathrm{d} \mathrm{Cl}(\mathrm{n}=47) \\
\text { vs. } 4 \times 3 \mathrm{~g} / \mathrm{d} \| \\
(\mathrm{n}=51)\end{array}$ & $\begin{array}{l}\text { Prospective, open- } \\
\text { label controlled } \\
\text { study }\end{array}$ & $\begin{array}{l}\text { Clinical cure } \\
\text { Microbiological cure } \\
\text { Days to } \\
\text { defervescence } \\
\text { Level } 1 \text { costs } \\
\text { Level } 2 \text { costs }\end{array}$ & $\begin{array}{l}\text { NS } \\
\text { NS } \\
\mathrm{Cl}<\| \\
(p=0.012) \\
\mathrm{NS} \\
\mathrm{Cl}<\| \\
(p=0.028)\end{array}$ & \\
\hline $\begin{array}{l}\text { Lau } 2006 \\
{[42]}\end{array}$ & Piperacillin-tazobactam & $\begin{array}{l}\text { Complicated intra- } \\
\text { abdominal } \\
\text { infections }\end{array}$ & $\begin{array}{l}12 \mathrm{~g} / \mathrm{d} \mathrm{Cl}(\mathrm{n}=130) \\
\text { vs. } 4 \times 3 \mathrm{~g} / \mathrm{d} \mathrm{II} \\
(\mathrm{n}=132)\end{array}$ & $\mathrm{RCT}$ & $\begin{array}{l}\text { Clinical cure } \\
\text { Mortality } \\
\text { Adverse events }\end{array}$ & $\begin{array}{l}\text { NS } \\
\text { NS } \\
\text { NS }\end{array}$ & \\
\hline $\begin{array}{l}\text { *Rafati } 2006 \\
{[16]}\end{array}$ & Piperacillin & $\begin{array}{l}\text { Septic, critically ill } \\
\text { patients }\end{array}$ & $\begin{array}{l}8 \mathrm{~g} / \mathrm{d} \mathrm{Cl}(\mathrm{n}=20) \\
\text { vs. } 4 \times 3 \mathrm{~g} / \mathrm{d} \| \\
(\mathrm{n}=20)\end{array}$ & RCT & $\begin{array}{l}\text { Mortality } \\
\text { Rate of decrease } \\
\text { APACHE II score } \\
\text { Days to } \\
\text { defervescence }\end{array}$ & $\begin{array}{l}\mathrm{NS} \\
\mathrm{Cl}>\| \\
\mathrm{NS}\end{array}$ & Lower antimicrobial dose in $\mathrm{Cl}$ group \\
\hline $\begin{array}{l}\text { *Lodise } 2007 \\
\text { [50] }\end{array}$ & $\begin{array}{l}\text { Piperacillin- } \\
\text { tazobactam }\end{array}$ & $\begin{array}{l}\text { Pseudomonas aeruginosa } \\
\text { infections, including both } \\
\text { ICU patients }(n=126) \text { and } \\
\text { non-ICU patients }(n=68)\end{array}$ & $\begin{array}{l}3 \times 3.375 \mathrm{~g} / \mathrm{d} \text { in } \\
\text { extended infusions } \\
\text { of } 4 \mathrm{~h}(\mathrm{n}=102) \mathrm{vs} . \\
4 \text { or } 6 \times 3.375 \mathrm{~g} / \mathrm{d} \text { II } \\
(\mathrm{n}=92)\end{array}$ & $\begin{array}{l}\text { Retrospective } \\
\text { cohort study }\end{array}$ & $\begin{array}{l}\text { 14-day mortality } \\
\text { APACHE } \|<17 \\
\text { APACHE } \| \geq 17 \\
\text { Length of stay: } \\
\text { APACHE } \|<17 \\
\text { APACHE } \| \geq 17\end{array}$ & $\begin{array}{l}\text { NSExtended } \\
\text { infusion }<11 \\
(p=0,04) \\
\text { NSExtended } \\
\text { infusion }<11 \\
(p=0,02)\end{array}$ & $\begin{array}{l}\text { Lower antimicrobial dose in extended infusion } \\
\text { group Significant outcome differences only in } \\
\text { subpopulation with high severity of illness } \\
\text { (APACHE } \| \geq 17 \text { ) }\end{array}$ \\
\hline $\begin{array}{l}\text { *Lorente } 2009 \\
\text { [51] }\end{array}$ & $\begin{array}{l}\text { Piperacillin- } \\
\text { tazobactam } \\
(+ \text { tobramycin } \\
7 \mathrm{mg} / \mathrm{kg} / \mathrm{d})\end{array}$ & VAP & $\begin{array}{l}16 \mathrm{~g} / \mathrm{d} \mathrm{Cl}(\mathrm{n}=37) \text { vs. } \\
4 \times 4 \mathrm{~g} / \mathrm{d} \|(n=46)\end{array}$ & $\begin{array}{l}\text { Retrospective } \\
\text { cohort study }\end{array}$ & $\begin{array}{l}\text { Clinical cure: } \\
\mathrm{MIC}=4 \mu \mathrm{g} / \mathrm{ml} \\
\mathrm{MIC}=8 \mu \mathrm{g} / \mathrm{ml} \\
\mathrm{MIC}=16 \mu \mathrm{g} / \mathrm{ml}\end{array}$ & $\begin{array}{l}\mathrm{NSCl}>\|(p=0.02) \\
\mathrm{Cl}>\|(p=0.02)\end{array}$ & $\begin{array}{l}\text { Significant outcome differences only in infections } \\
\text { caused by pathogens with high MICs }\end{array}$ \\
\hline
\end{tabular}

*Studies that included critically ill, ICU patients.

$\mathrm{NS}=$ nonsignificant; $\mathrm{MIC}=$ minimal inhibitory concentration; $\mathrm{Cl}=$ continuous infusion; II = intermittent infusion; APACHE II = Acute Physiology and Chronic Health Evaluation; VAP= ventilator-associated pneumonia; $\mathrm{RCT}=$ randomized, controlled trial; $\mathrm{ICU}=$ intensive care unit. 
combination of pathogens with MICs close to the susceptibility breakpoint and critically ill patients with lower than expected Css (because of increased Vd and increased drug clearance) can lead to critically low Css/MIC ratios below the advised ratio of 2.5 to 4 . An overview of studies $[11,15,25-33]$ investigating PK-parameters of continuous infusion of different antimicrobials in critically ill patients is shown in Table 1 . In most of these studies, the Css/MIC ratio is well above 2.5. However, for cefepime (at a submaximal dosage of $4 \mathrm{~g} / \mathrm{d}$ ) [31] and piperacillin (at a submaximal dosage of $12 \mathrm{~g} / \mathrm{d}$ ) [33], the ratio became problematically low for pathogens with MICs close to the susceptibility breakpoint with subsequent risk of therapeutic failure or emergence of resistance. Yet, for any MIC, continuous infusion has a higher likelihood of attaining PK/PD targets than II. So when starting empirical therapy, CI is the safer choice. If however after culture the pathogen proves to be resistant (or even in the intermediate range) another antimicrobial should be chosen. Obtaining a MIC for the causative pathogen in case of severe infection will give even more information than relying on "susceptible/intermediate/resistant" categories only. The value of the MIC can be directly compared with the breakpoints and can be used to guide therapy.

\section{General clinical value of $\mathrm{Cl}$ of $\beta$-lactam antibiotics}

In 2009, a meta-analysis was published of all randomized controlled trials (RCT) from 1950 through November 2007 comparing the clinical benefits of $\mathrm{CI}$ regimens of betalactam antibiotics with II regimens [34]. The meta-analysis included 14 RCTs with a total of 846 patients [16,17,25,3544]. No difference was found for mortality or clinical cure between II or CI. Yet, all but one of the included studies used a higher drug dose in the bolus group than in the CI group, and the authors concluded that CI of a lower dosed beta-lactam antibiotic might lead to the same clinical results as II of the same higher dosed antibiotic. Apart from the different daily dosages, another important limitation was that most studies analyzed a heterogeneous population with underrepresentation of the critically ill, a population where CI is expected to be advantageous.

\section{Penicillins}

For penicillin $\mathrm{G}$ and flucloxacillin, most data come from observational, noncontrolled studies often in homebased care settings [45-47]. Both antibiotics proved to be safe when given in CI and achieved an excellent clinical cure rate in stable, noncritically ill patients. Only one study included critically ill patients, but CI was only started after clinical improvement was achieved with II [47]. All previous studies had no comparator group of patients with II. One retrospective study did compare outcome between CI $(n=78)$ and II $(n=28)$ of oxacillin for treatment of MSSA (methicillin susceptible Staphylococcus aureus) endocarditis. They found similar results for mortality ( $8 \%$ vs. $10 \%, p=0.7$ ) and length of stay, but microbiological cure at 30 days, defined as "no positive cultures within 30 days of the end of treatment", differed significantly with odds ratio of 3.8 in favor of CI [48].

Five clinical trials have been published in regards to CI of piperacillin-tazobactam (Table 2). Two of these found no difference for clinical cure rates between CI and II of piperacillin-tazobactam [42,49], although Grant et al. [49] concluded that the costs in the CI group were significantly lower than in the II group. These two studies did not include critically ill patients. Others observed that the severity of illness, measured by APACHE II scores, decreased more rapidly in the CI group of septic patients even though this group received a lower daily dosage [16]. Two retrospective cohort studies described higher rates of clinical cure in the CI arm, but only in subpopulations with the most critically ill patients [50] or with infections caused by more resistant organisms [51]. The last three studies were performed with critically ill, intensive care unit (ICU) patients.

\section{Cephalosporins}

Studies comparing clinical outcome between CI and II of cephalosporins are listed in Table 3. Four showed comparable clinical cure rates $[17,28,38,41]$. However, most used a lower daily dose in the CI arm than in the II arm $[17,28,38]$. In the studies by Hanes and Georges, both $\mathrm{CI}$ and II regimens achieved T $>$ MIC $>90 \%$, which explains the comparable outcomes $[28,41]$.

Three studies showed a clinical advantage with continuous infusion; however, mostly only in a subpopulation. Roberts and coworkers [35] compared CI of ceftriaxone versus II in 57 intensive care patients with sepsis and found a significant advantage in favor of CI only in an $a$ priori-defined subgroup of patients $(n=50)$ who received more than 4 days of antibiotic therapy, but not in the intention-to-treat analysis that included all patients $(n=57)$. This subgroup analysis was performed to exclude patients who were either moribund (too ill) or did not need antimicrobial treatment (not ill enough). A retrospective study by Lorente et al. showed a greater clinical cure rate for CI versus II of ceftazidime (and tobramycin) for the treatment of critically ill patients with ventilatorassociated pneumonia (VAP) [52]. Both arms received a low total daily dose of $4 \mathrm{~g} / \mathrm{d}$ (instead of the standard dosage of $6 \mathrm{~g} / \mathrm{d}$ ). This could have influenced results, because with suboptimal dosages the chances to attain an acceptable T $>$ MIC are much higher with CI. Finally, an older study [36] found that continuous cefamandole infusion (with carbenicillin in II) achieved a greater effectiveness than intermittent carbenicillin infusion (with carbenicillin in II) in a subgroup of patients with persistent severe neutropenia. 
Table 3 Characteristics of studies comparing outcome for continuous versus intermittent administration of cephalosporins

\begin{tabular}{|c|c|c|c|c|c|c|c|}
\hline Study & Drug & Patient population & Dosage & Study type & Outcome measure & Outcome & Remarks \\
\hline $\begin{array}{l}\text { Bodey } 1979 \\
{[36]}\end{array}$ & $\begin{array}{l}\text { Cefamandole } \\
(+ \text { carbenicillin } \\
6 \times 5 \mathrm{~g} / \mathrm{d})\end{array}$ & $\begin{array}{l}\text { FUO in neutropenic } \\
\text { patients }\end{array}$ & $\begin{array}{l}12 \mathrm{~g} / \mathrm{d} \mathrm{Cl}(\mathrm{n}=74) \text { vs. } \\
4 \times 3 \mathrm{~g} / \mathrm{d} \mathrm{II}(\mathrm{n}=92)\end{array}$ & $\mathrm{RCT}$ & Clinical cure & NS & $\begin{array}{l}\text { Significant difference in clinical cure (in favor of } \mathrm{Cl} \text { ) } \\
\text { only in subpopulation with persistent neutropenia } \\
(p=0.03)\end{array}$ \\
\hline $\begin{array}{l}\text { *Hanes } 2000 \\
{[28]}\end{array}$ & Ceftazidime & $\begin{array}{l}\text { Nosocomial pneumonia } \\
\text { in critically ill trauma } \\
\text { patients }\end{array}$ & $\begin{array}{l}60 \mathrm{mg} / \mathrm{kg} / \mathrm{d} \mathrm{Cl}(\mathrm{n}=17) \\
\text { vs. } 3 \times 2 \mathrm{~g} / \mathrm{d} \mathrm{II}(\mathrm{n}=15)\end{array}$ & $\mathrm{RCT}$ & $\begin{array}{l}\text { Length of stay } \\
\text { Duration of } \\
\text { leucocytosis } \\
\text { Days to } \\
\text { defervescence }\end{array}$ & $\begin{array}{l}\text { NS } \\
\text { NS } \\
\text { NS }\end{array}$ & $\begin{array}{l}\mathrm{T}>\mathrm{MIC}>90 \% \text { in both II and } \mathrm{Cl} \text { groupLower } \\
\text { antimicrobial dose in } \mathrm{Cl} \text { group }\end{array}$ \\
\hline $\begin{array}{l}\text { *Nicolau } 2001 \\
{[38]}\end{array}$ & $\begin{array}{l}\text { Ceftazidime } \\
\text { (+tobramycin } \\
7 \mathrm{mg} / \mathrm{kg} / \mathrm{d} \text { ) }\end{array}$ & $\begin{array}{l}\text { Nosocomial pneumonia } \\
\text { in ICU patients }\end{array}$ & $\begin{array}{l}3 \mathrm{~g} / \mathrm{d} \mathrm{Cl}(\mathrm{n}=17) \mathrm{vs} \\
3 \times 2 \mathrm{~g} / \mathrm{d} \|(\mathrm{n}=18)\end{array}$ & $\mathrm{RCT}$ & $\begin{array}{l}\text { Clinical cure } \\
\text { Microbiological } \\
\text { cure }\end{array}$ & $\begin{array}{l}\text { NS } \\
\text { NS }\end{array}$ & Lower antimicrobial dose in $\mathrm{Cl}$ group \\
\hline $\begin{array}{l}\text { *Lorente } 2007 \\
{[52]}\end{array}$ & $\begin{array}{l}\text { Ceftazidime } \\
\text { (+tobramycin } \\
7 \mathrm{mg} / \mathrm{kg} \text { ) }\end{array}$ & VAP & $\begin{array}{l}4 \mathrm{~g} / \mathrm{d} \mathrm{Cl}(\mathrm{n}=56) \text { vs. } \\
2 \times 2 \mathrm{~g} / \mathrm{d} \|(\mathrm{n}=65)\end{array}$ & $\begin{array}{l}\text { Retrospective, } \\
\text { nonrandomized, } \\
\text { historical } \\
\text { chart review }\end{array}$ & Clinical cure & $C l>\|(p<0.001)$ & \\
\hline $\begin{array}{l}\text { *Roberts } 2007 \\
{[35]}\end{array}$ & Ceftriaxone & Sepsis & $\begin{array}{l}2 \mathrm{~g} / \mathrm{d} \mathrm{Cl}(\mathrm{n}=29) \mathrm{vs} \\
1 \times 2 \mathrm{~g} / \mathrm{d} \|(\mathrm{n}=28)\end{array}$ & $\mathrm{RCT}$ & $\begin{array}{l}\text { Clinical cure- } \\
\text { ITT analysis } \\
\text { a priori }\end{array}$ & $\begin{array}{l}\text { NS } \\
\mathrm{Cl}>\| \\
(p=0.04)\end{array}$ & $\begin{array}{l}\text { Significant difference in clinical cure only in an 'a priori' } \\
\text { defined subgroup of patients who received at least } 4 \\
\text { days of ceftriaxone therapy (to exclude patients that } \\
\text { were not ill enough or too ill) }\end{array}$ \\
\hline $\begin{array}{l}\text { Van Zanten } \\
\text { 2007[17] }\end{array}$ & Cefotaxime & COPD exacerbations & $\begin{array}{l}2 \mathrm{~g} / \mathrm{d} \mathrm{Cl}(\mathrm{n}=47) \text { vs. } \\
3 \times 1 \mathrm{~g} / \mathrm{d} \|(\mathrm{n}=46)\end{array}$ & $\mathrm{RCT}$ & Clinical cure & NS & Lower antimicrobial dose in $\mathrm{Cl}$ group \\
\hline $\begin{array}{l}{ }^{*} \text { Georges } 2005 \\
{[41]}\end{array}$ & $\begin{array}{l}\text { Cefepime } \\
(+ \text { amikacin } \\
15 \mathrm{mg} / \mathrm{kg} / \mathrm{d})\end{array}$ & $\begin{array}{l}\text { Severe pneumonia } \\
\text { or bacteremia }\end{array}$ & $\begin{array}{l}4 \mathrm{~g} / \mathrm{d} \mathrm{Cl}(\mathrm{n}=26) \mathrm{vs} . \\
2 \times 2 \mathrm{~g} / \mathrm{d} \|(\mathrm{n}=24)\end{array}$ & $\mathrm{RCT}$ & Clinical cure & NS & \\
\hline
\end{tabular}

*Studies that included critically ill, ICU patients.

$\mathrm{FUO}=$ fever of unknown origin; $\mathrm{NS}=$ nonsignificant; $\mathrm{RCT}=$ randomized, controlled trial; $\mathrm{ITT}=$ intention to treat; $\mathrm{Cl}=$ continuous infusion; $\| \mathrm{l}=$ intermittent infusion; $\mathrm{VAP}=$ ventilator-associated pneumonia; $\mathrm{ICU}=$ intensive care unit. 


\section{Carbapenems}

A retrospective cohort study with 89 patients [53] comparing CI versus II of meropenem for the treatment of VAP due to Gram-negative bacilli found a significantly better clinical cure rate in the group with CI, especially when used for Pseudomonas species and other pathogens with elevated MIC values. The authors used 6-h infusions, although it is generally not advised to give meropenem in infusions longer than $3-4 \mathrm{~h}$ for reasons of stability. Sakka conducted a study in which 20 critically ill patients with pneumonia were randomized to receive either a normal dose $(3 \times 1 \mathrm{~g} / \mathrm{d})$ of imipenemcilastatin by II $(n=10)$ or a lower dose $(2 \mathrm{~g} / \mathrm{d})$ by CI $(n=10)$ [44]. Both regimens achieved excellent target attainment with $\mathrm{T}>\mathrm{MIC} 100 \%$ for all patients, which explains the similar outcomes with one patient who died in the CI group and two patients in the II group. Both studies are listed in Table 4.

With regards to the threat of the emerging carbapenemase-producing Enterobacteriaceae, it has been suggested in a recent review that carbapenemase-producing Klebsiella pneumoniae with a MIC up to $4 \mathrm{mg} / \mathrm{L}$ (higher than the EUCAST (European Committee on Antimicrobial Susceptibility Testing) susceptibility breakpoint of $2 \mathrm{mg} / \mathrm{L}$ and the CLSI (Clinical and Laboratory Standards Institute) susceptibility breakpoint of $1 \mathrm{mg} / \mathrm{L}$ can still be treated with carbapenems if they are given in an extended infusion and higher dosage regimen [54]. This could create a treatment option in situations where alternatives are extremely limited.

\section{Temocillin}

Only one study has been published concerning CI of the niche antibiotic temocillin [13]. Temocillin remains stable and therefore active in $\mathrm{CI}$ and is compatible with aminoglycosides (but not with several other antibiotics). Moreover, the standard dose of $4 \mathrm{~g} / \mathrm{d}$ yields stable serum concentrations $>16 \mathrm{mg} / \mathrm{L}$, the breakpoint of temocillin for Enterobacteriaceae. Unfortunately, the study was not powered to compare clinical outcome. A study using a 6-g/d dosage in the ICU with a measure of clinical outcome is now near completion.

\section{$\mathrm{Cl}$ of beta-lactam antibiotics: Discussion}

The available clinical evidence, also in critically ill patients, does not show a conclusive and significant benefit in favor of CI. This might be due to the fact that $\mathrm{CI}$ is only likely to have clinical benefits in the subpopulation of patients for whom II is unable to achieve an adequate T > MIC: for example, in patients with infections caused by borderline susceptible organisms, patients with elevated drug clearance or increased $V_{d}$ (such as the critically ill), and possibly also immunocompromised patients. These populations are difficult to include in homogenous cohorts, and the underlying pathologies may obscure the final picture. However, it is fair to say that in the small numbers of clinical studies that did show an advantage in favor of $\mathrm{CI}$, this effect was only present or more pronounced in a subpopulation of the most critically ill or patients with infections caused by pathogens with elevated MICs. An important limitation of most of the older studies is that they are primarily designed to prove that a lower dose of an antibiotic given in CI can be equally effective as a higher dose given in an intermittent bolus regimen and consequently use lower dosages in the $\mathrm{CI}$ arm. Finally, some studies use a second antibiotic, which could be responsible for bias.

Future studies should ideally include a homogeneous population and PK/PD analysis (including the MICs of the responsible pathogens and therapeutic drug monitoring) to know which patients attain PK/PD targets and how this is linked with either infusion regimen and/or outcome. However, serum level determinations for beta-lactam antibiotics are not routinely available, and therefore, PK/PD analysis has only recently gained attention in the ICU world.

Apart from clinical efficacy, there are some other advantages in favor of CI. Several studies show that the costs associated with CI are lower than with II $[49,55]$. There also is some evidence that tissue penetration might be better with CI. Roberts et al. found that concentration at the subcutaneous tissue was higher when meropenem was administered by CI than when it was administered by II in critically ill patients [15]. Another study shows that the penetration of ceftazidime in patients with severe abdominal infections was better with CI than with II [26].

Table 4 Characteristics of studies comparing outcome for continuous versus intermittent administration of carbapenems

\begin{tabular}{|c|c|c|c|c|c|c|c|}
\hline Study & Drug & $\begin{array}{l}\text { Patient } \\
\text { population }\end{array}$ & Dosage & Study type & $\begin{array}{l}\text { Outcome } \\
\text { measure }\end{array}$ & Outcome & Remarks \\
\hline $\begin{array}{l}\text { *Lorente } \\
2006[53]\end{array}$ & Meropenem & $\begin{array}{l}\text { VAP with gram } \\
\text { negative bacilli }\end{array}$ & $\begin{array}{l}4 \mathrm{~g} / \mathrm{d} \mathrm{Cl}(\mathrm{n}=42) \\
\text { vs. } 4 \times 1 \mathrm{~g} / \mathrm{d}(\mathrm{n}=47)\end{array}$ & $\begin{array}{l}\text { Retrospective } \\
\text { cohort study }\end{array}$ & Clinical cure & $\mathrm{Cl}>\| \mathrm{I}(p<0.001)$ & \\
\hline $\begin{array}{l}\text { *Sakka } \\
\text { 2007[44] }\end{array}$ & Imipenem-cilastatin & $\begin{array}{l}\text { Nosocomial } \\
\text { pneumonia }\end{array}$ & $\begin{array}{l}2 \mathrm{~g} / \mathrm{d} \mathrm{Cl}(\mathrm{n}=10) \\
\text { vs. } 3 \times 1 \mathrm{~g} / \mathrm{d}(\mathrm{n}=10)\end{array}$ & $\mathrm{RCT}$ & Clinical cure & NS & $\begin{array}{l}\text { Lower antimicrobial dose in } \\
\mathrm{Cl} \text { groupT }>\mathrm{MIC}=100 \% \text { in } \\
\text { both } \| \text { and } \mathrm{Cl} \text { group }\end{array}$ \\
\hline
\end{tabular}

*Studies that included critically ill, ICU patients.

$\mathrm{VAP}=$ ventilator-associated pneumonia; $\mathrm{RCT}=$ randomized, controlled trial. 


\section{$\mathrm{Cl}$ of beta-lactam antibiotics: Practical considerations}

The antibiotic dosage should be adjusted to achieve a serum steady state target concentration approximately four times the MIC of the pathogen, and a loading dose should be administered to reach a steady state more rapidly. Several formulas have been proposed for calculation of loading dose and total daily dose [56]:

Total daily dosage $(\mathrm{mg})=24(\mathrm{~h}) \mathrm{x}$ total body clearance $(\mathrm{L} / \mathrm{h}) \mathrm{x}$ target Css $(\mathrm{mg} / \mathrm{L})$

Loading dose $(\mathrm{mg})=$ target peak concentration $(\mathrm{mg} / \mathrm{L})$ $\mathrm{x}$ volume of distribution (l)

$\mathrm{AUC}_{24 \mathrm{~h}}=$ Total daily dosage $/[\{$ (creatinine clearance $\mathrm{x}$ $0.79)+15.43 \times 0.06]$

However, the value of these formulas is limited in a critically ill population; they presume knowledge of volume of distribution $\left(\mathrm{V}_{\mathrm{d}}\right)$ and total body clearance (TBC), which is problematic in an ICU population. In critically ill patients, the $V_{d}$ is elevated and difficult to predict. Second, the TBC of beta-lactams is not always readily predictable from the value of creatinine clearance (even for antibiotics such as ceftazidime that are essentially eliminated by the kidney), and moreover, in the critically ill there is no readily available method to measure accurately the glomerular filtration rate (GFR) [57]. The risk of underdosing is certainly higher than the risk of possible toxicity in ICU patients. Because no clinical or biological variable can predict betalactam concentrations in critically ill patients, we agree with other authors that therapeutic drug monitoring of beta-lactam antibiotics might be necessary in this population [58]. Because beta-lactams are rather safe drugs, a practical approach commonly used is to start with a loading dose equal to the first dose normally administered when using II, followed immediately by CI using the same total daily dose as in II (note that in doing so, one creates essentially a single serum peak equivalent to what is obtained repeatedly with II).
Not all beta-lactam antibiotics are stable enough for a 24-h infusion. Piperacillin [59], temocillin [13], and aztreonam $[59,60]$ are stable at room temperature for at least $24 \mathrm{~h}$. Ceftazidime and cefepime are stable for $24 \mathrm{~h}$ at $25^{\circ} \mathrm{C}$, but only for $8 \mathrm{~h}$ and $13 \mathrm{~h}$, respectively, at $37^{\circ} \mathrm{C}$ $[59,61,62]$. This means they can be used as $24-\mathrm{h}$ infusion without problems if temperature does not exceed $25^{\circ} \mathrm{C}$, but home administration with portable pumps next to the body or hospital administration in regions or periods of warm climate can pose problems because of higher temperatures. Meropenem, doripenem, and especially imipenem are less stable and should only be given as extended 3- or 4-h infusions [63]. Amoxicillin is stable at room temperature for $8 \mathrm{~h}$ [64] and penicillin for $12 \mathrm{~h}$ [65]. Certain physical or chemical incompatibilities with other drugs for infusion through the same intravenous line (Y-site infusion) have been described. Most notable is the incompatibility with vancomycin for most betalactam antibiotics. An overview of all incompatibilities is listed in Table 5. If concomitant administration of Y-site incompatible drugs is necessary, they should be administrated trough separate intravenous lines.

\section{Vancomycin}

Vancomycin has a different PK/PD pattern. Like betalactam antibiotics, vancomycin also exhibits slow and time-dependent killing during in vitro experiments. However, unlike the beta-lactams, vancomycin has moderately long postantibiotic effects (i.e., withdrawal of the antibiotic is not immediately followed by bacterial regrowth). Therefore, it becomes less important for serum concentrations to remain above the MIC all the time [66]. Moreover, vancomycin has a much longer serum half-life than most $\beta$-lactams, which makes the drug remain above the MIC for most of the administration interval (especially if considering the recently revised clinical breakpoints of 
vancomycin that have been decreased to $\leq 2 \mathrm{mg} / \mathrm{L}$ for susceptible and to $>2$ for resistant to avoid recommending the use of vancomycin against organisms with higher MICs that would only poorly respond to the antibiotic). Careful animal studies where $\mathrm{T}>$ MIC could be unambiguously separated from other PK parameters (which is difficult to obtain in human studies) showed that it is actually $\mathrm{AUC}_{24 \mathrm{~h}} / \mathrm{MIC}$ (area under the curve over $24 \mathrm{~h}$ ) that best predicts clinical efficacy [67-70].

$\mathrm{AUC}_{24 \mathrm{~h}}$ is a parameter that is more difficult to grasp than the $\mathrm{T}>\mathrm{MIC}$, but it is proportional to the total daily dosage (TDD) and inversely proportional to the creatinine clearance $(\mathrm{CrCl})$ [69]. Consequently the $\mathrm{AUC}_{24 \mathrm{~h}}$ will increase if a greater TDD is given, irrespective of continuous or intermittent dosing. An $\mathrm{AUC}_{24 \mathrm{~h}} / \mathrm{MIC}>350$ was associated with clinical success and an $\mathrm{AUC}_{24 \mathrm{~h}} / \mathrm{MIC}>400$ with faster bacterial eradication in patients receiving vancomycin for Staphylococcus aureus pneumonia [69]. In continuous infusion, the $\mathrm{AUC}_{24 \mathrm{~h}}$ is simply the product of the actual serum concentration $\mathrm{x} 24$. Based on the above observations concerning the required $\mathrm{AUC}_{24 \mathrm{~h}} / \mathrm{MIC}$ ratio, it means that a stable serum level of 14 to 18 times the MIC must be maintained to achieve optimal efficacy.

\section{Clinical value of $\mathrm{Cl}$ of vancomycin}

A prospective, randomized trial in 114 patients treated for severe staphylococcal infections compared outcome, safety, and cost of CI versus II infusion of vancomycin [71]. Outcome and safety were similar between the two groups, but with CI target concentrations were achieved more quickly, there was less variability of $\mathrm{AUC}_{24 \mathrm{~h}}$ values, and costs were lower. Vuagnat et al. conducted a nonrandomized, prospective trial with 44 patients who required high-dose vancomycin for treatment of osteomyelitis [72]. Twenty-one patients received vancomycin through II and 23 through CI. Outcome was equal with both regimens but with $\mathrm{CI}$ target concentrations were achieved more quickly, there was less variability of serum concentrations and also less adverse reactions were seen, including renal injury. A small, retrospective study in critically ill patients found that CI was associated with a faster decrease in leukocyte count and clinical severity score but not with differences in morbidity or mortality [73]. One matched cohort study reported lower mortality rates for critically ill patients with VAP receiving vancomycin in CI (25\% vs. $55 \%)$. Multiple regression analysis of the data confirmed that CI was associated with improved survival. Unfortunately, this study was not designed to compare $\mathrm{CI}$ and $\mathrm{II}$ and thus PK/PD data are lacking [74].

Two major clinical studies compared nephrotoxicity between different vancomycin dosing regimens $[75,76]$. In a study in which 167 outpatients received vancomycin through CI $(\mathrm{n}=112)$ or through II $(\mathrm{n}=55)$, Ingram et al. found that $\mathrm{CI}$ is associated with a slower onset, but not a lower prevalence (15.6\%), of nephrotoxicity [75]. A nonsignificant tendency toward less nephrotoxicity in favor of CI was seen in 149 patients after cardiac surgery [76].

Byl et al. compared the pleural and serum vancomycin concentrations in 16 patients receiving continuous or intermittent vancomycin infusion and found no difference for $\mathrm{AUC}_{24 \mathrm{~h}}$ between the two groups, but antibiotic levels were more sustained with CI [77].

\section{$\mathrm{Cl}$ of vancomycin: Discussion}

The actual data show no difference in clinical outcome between continuous and intermittent dosing regimens. But for vancomycin, in contrast to the beta-lactams, we expected this; as we have seen, $\mathrm{AUC}_{24 \mathrm{~h}} / \mathrm{MIC}$ is the $\mathrm{PK} /$ PD parameter best predictive of clinical efficacy and is dependent only on TDD and renal function.

If not for attaining better clinical efficacy, what other reasons are there for choosing a CI regimen? The study from Wysocki et al. suggests that $\mathrm{CI}$ is cheaper, logistically more convenient, achieves target concentrations faster, and results in less variability of the AUC24 compared with II [71]. On a busy nursing ward, it may be easier to obtain a reliable Css than a reliable through concentration, because the first can be obtained at almost any time during the administration period.

The subject of nephrotoxicity is of growing importance, because there is a tendency toward higher, and potentially more nephrotoxic, dosing of vancomycin to attain the advocated PK/PD-target of $\mathrm{AUC}_{24 \mathrm{~h}}>400 / \mathrm{MIC}$. As mentioned, two studies have suggested that $\mathrm{CI}$ might be associated with a slower onset of nephrotoxicity [75,76]. Wysocki et al. [71] also states that continuous infusion with a target Css of $20-25 \mathrm{mg} / \mathrm{L}$ is safe, and a recent metaanalysis of available data found that $\mathrm{CI}$ is associated with a significantly lower risk of nephrotoxicity compared with II [78]. However, a recent, retrospective, cohort study of 129 patients who received vancomycin in CI with a target Css of $15-25 \mu \mathrm{g} / \mathrm{mL}$ contradicts the belief that $\mathrm{CI}$ is less nephrotoxic than II and finds a high proportion of patients with acute kidney injury (29.5\%) [79]. This study had no comparator group of patients with II. Data on toxicity for continuous versus intermittent infusion of vancomycin are conflicting, and no conclusive recommendations can be made [80].

Because there is no evidence for outcome benefit and because data on renal toxicity are conflicting, recent guidelines from the Infectious Diseases Society of America (IDSA) concerning the treatment of methicillinresistant Staphylococcus aureus (MRSA) do not support the generalized use of a continuous infusion for vancomycin in these circumstances [81]. 


\section{$\mathrm{Cl}$ of vancomycin: Practical considerations}

Recent consensus recommendations suggest a vancomycin starting dose of $15-20 \mathrm{mg} / \mathrm{kg}$ every $8-12 \mathrm{~h}$ for II with a loading dose of $25-30 \mathrm{mg} / \mathrm{kg}$ [70]. These recommendations for loading dose and TDD can be applied to CI or the dosages can be individualized according to PK/PD targets. The formulas proposed for calculation of individualized dosages are the same as those mentioned for beta-lactam antibiotics. These formulas also suffer from the same shortcomings, as mentioned, for beta-lactam antibiotics and are not readily applicable in critically ill patients. However, they can be used to demonstrate the thin line between therapeutic and toxic vancomycin dosages. For example, attaining an $\mathrm{AUC}_{24 \mathrm{~h}} / \mathrm{MIC}$ of 400 for a patient with a $\mathrm{CrCl}$ of $100 \mathrm{ml} / \mathrm{min}$ and a pathogen with a MIC of $1 \mathrm{mg} / \mathrm{L}$ would require a total daily dose of $2,300 \mathrm{mg}$ of vancomycin. For a MIC of $2 \mathrm{mg} / \mathrm{L}$ (the EUCAST susceptibility breakpoint for vancomycin against MRSA), this would mean a total daily dose of 4,500 mg, which approximates a Css of $31.25 \mathrm{mg} / \mathrm{L}$. Ingram et al. [82] showed that the risk for development of acute kidney injury greatly increases when Css exceeds $28 \mathrm{mg} / \mathrm{L}$ and $31.5 \mathrm{mg} / \mathrm{L}$ is already well above this safety limit. A target Css less than $28 \mathrm{mg} / \mathrm{L}$ is achievable only for a pathogen with a MIC of maximal $1.8 \mathrm{mg} / \mathrm{L}$. If the MIC of the pathogen is not known, an empirical target Css of 20$25 \mathrm{mg} / \mathrm{L}$ can be used. Jeurissen showed that to achieve a target of $25 \mathrm{mg} / \mathrm{L}$ a TDD of 3,000 mg with a loading dose of 1,000 mg should be used in critically ill patients [83]. Because of the difficulties in predicting correctly both the $V_{d}$ and the clearance of vancomycin, it remains advisable to measure serum levels during the first days of therapy so that adjustments can be made rapidly.

Vancomycin is stable at room temperature for at least $24 \mathrm{~h}$ and can be given in CI. However, the drug is incompatible with several other drugs, including most notably $\beta$-lactams [64]. Clinicians, therefore, are advised to infuse vancomycin through a separate line than the one used for other drugs. Incompatibilities are listed in Table 5. Because of the risk of red-man syndrome, it also is advisable to administer the loading dose in no less than $1-2 \mathrm{~h}$ and to use only diluted solutions of vancomycin (typically no more than $10 \mathrm{~g} / \mathrm{L}$ in $5 \%$ glucose).

\section{Drawbacks of continuous infusion}

Most notable disadvantages of continuous infusion are related to the stability of the administered drug, especially for carbapenems, and incompatibilities with other drugs as mentioned before. For carbapenems, this limits their use as "prolonged infusion" (3-4 h), unless solutions are regularly replaced or special precautions are used, such as maintaining the solutions at $4^{\circ} \mathrm{C}$. For ceftazidime, the instability issues will become important if the surrounding temperature exceeds $25^{\circ} \mathrm{C}$ and may necessitate a frequent replacement (every $8 \mathrm{~h}$ ) of the solutions. In the ICU, the incompatibility problem is partly overcome through the frequent use of multiple lumen central venous catheters. However, on a classic nursing ward where most patients have standard peripheral venous catheters, this can pose practical problems. Clinicians should be advised to check for potential incompatibilities before starting CI (e.g., refer to the lists in $[61,62])$ and, in case of difficulty, to resort to extended dosing regimens (thus alternating the infusion of the antibiotic with that of the incompatible drug(s).

Another caveat concerns specifically the beta-lactams, which is the risk of neurological toxicity (encephalopathy, convulsions). Beta-lactams are known to cause such adverse effects, but most published studies abut CI did not report its occurrence in patients. Nevertheless, there are anecdotal reports for neurological adverse effects caused by cefepime given by CI (especially if its concentrations exceed $80 \mathrm{mg} / \mathrm{L}$ ), for reasons that could be related both to the drug intrinsic toxic potential and the liberation of degradation products (see discussion in [62]). Conversely, no adverse effect was noted for temocillin, including in patients with stable levels between 80 and $140 \mathrm{mg} / \mathrm{L}$. Nevertheless, the clinician should remain aware of this risk, especially if deciding to aim at a high serum levels, because of the presence of an organism with a high MIC.

\section{Conclusions}

The pursuit for clinical advantages of $\mathrm{CI}$ is still open. There is compelling evidence from PK/PD studies that CI of beta-lactam antibiotics is superior to II for attainment of PK/PD targets. Clinical studies have been less convincing and, although they show at least comparable outcomes between different regimens, they have not been able until now to show a significant benefit in favor of CI. However, several studies show important shortcomings, such as the use of lower antimicrobial dosages in the CI arm. We conclude that CI of beta-lactam antibiotics is not necessarily more advantageous for all patients. The benefit is probably most pronounced in infections with more resistant pathogens and in subpopulations, such as critically ill or immunocompromised patients. This remains to be proven in well-designed, clinical studies with simultaneous in depth PK/PD analysis.

For vancomycin, CI can be chosen, not always for better clinical efficacy, but because it is practical, cheaper, associated with less AUC24h-variability and easier to monitor. Moreover, it might be associated with a slower onset of nephrotoxicity. There is, however, still more to debate about this specific point, and we would strongly encourage more detailed studies in this context.

\footnotetext{
Abbreviations

$\mathrm{Cl}$ : Continuous infusion; II: Intermittent infusion; T> MIC: Time above the minimal inhibitory concentration; PK/PD: pharmacokinetic/ pharmacodynamic; MIC: minimal inhibitory concentration; $\mathrm{UUC}_{24 \mathrm{~h}}$ : Area under the curve over $24 \mathrm{~h} ; V_{d}$ : Volume of distribution; TBC: Total body
} 
clearance; RCT: Randomized controlled trial; MSSA: Methicillin susceptible Staphylococcus aureus; VAP: Ventilator-associated pneumonia; EUCAST: European Committee on Antimicrobial Susceptibility Testing; CLSI: Clinical and Laboratory Standards Institute; ICU: Intensive care unit; GFR: Glomerular filtration rate; $\mathrm{CrCl}$ : Creatinine clearance; TDD: Total daily dosage; Css: Steady state concentration; LD: Loading dose; Cpeak: Peak concentration; FUO: Fever of unknown origin; NS: Nonsignificant; ITT: Intention to treat; APACHE-II: Acute Physiology and Chronic Health Evaluation

\section{Competing interests}

The authors declare that they have no competing interests.

\section{Author's contributions}

$\mathrm{BVH}$ wrote the original draft of the paper. All authors have made substantial contributions to the analysis and interpretation of the literature survey, have been involved in revising the manuscript for important intellectual content, and have given final approval of the version to be published. Each author has participated sufficiently in the work to take public responsibility for appropriate portions of the content. All authors read and approved the final manuscript.

\section{Acknowledgments}

In loving memory of Dr. Axel Jeurissen

The authors thank clinical pharmacist John Leys, Antwerp University Hospital, for his help concerning drug incompatibilities.

\section{Author details}

'Department of Microbiology, Antwerp University Hospital, Edegem, Belgium. 2Department of Microbiology, GZA St. Vincentius Hospital, Antwerp, Belgium. ${ }^{3}$ Cellular and Molecular Pharmacology and Centre for Clinical Pharmacy, Louvain Drug Research Institute, Université catholique de Louvain, Brussels, Belgium. ${ }^{4}$ Department of Tropical Diseases, Antwerp University Hospital, Edegem, Belgium. ${ }^{5}$ nstitute of Tropical Medicine, Antwerp, Belgium. ${ }^{6}$ Department of Intensive Care Medicine, Antwerp University Hospital, Edegem, Belgium.

Received: 28 February 2012 Accepted: 2 July 2012

Published: 2 July 2012

\section{References}

1. Carlet J, Collignon P, Goldmann D, Goossens H, Gyssens IC, Harbarth S, Jarlier V, Levy SB, N'doye B, Pittet D, Richtmann R, Seto WH, Van der Meer JW, Voss A: Society's failure to protect a precious resource: antibiotics. Lancet 2011, 378(9788):369-371.

2. Boucher HW, Talbot GH, Bradley JS, Edwards JE, Gilbert D, Rice LB, Scheld M, Spellberg B, Bartlett J: Bad bugs, no drugs: no ESKAPE! An update from the Infectious Diseases Society of America. Clin Infect Dis 2009, 48(1):1-12.

3. Craig WA: Pharmacokinetic/pharmacodynamic parameters: rationale for antibiotic dosing of mice and men. Clin Infect Dis 1998, 26:1-10.

4. Mouton JW, Vinks AA: Is continuous infusion of beta-lactam antibiotics worthwhile?-efficacy and pharmacokinetic considerations. J Antimicrob Chemother 1996, 38(1):5-15.

5. Mouton JW, Punt N, Vinks AA: Concentration-effect relationship of ceftazidime explains why the time above the MIC is 40 percent for a static effect in vivo. Antimicrob Agents Chemother 2007, 51(9):3449-3451.

6. Craig WA: Interrelationship between pharmacokinetics and pharmacodynamics in determining dosing regimens for broad-spectrum cephalosporins. Diagn Microbiol Infect Dis 1995, 22:89-96.

7. Craig WA: Antimicrobial resistance issues of the future. Diagn Microbiol Infect Dis 1996, 25:213-217.

8. McKinnon PS, Paladino JA, Schentag JJ: Evaluation of area under the inhibitory curve (AUIC) and time above the minimum inhibitory concentration (T>MIC) as predictors of outcome for cefepime and ceftazidime in serious bacterial infections. Int J Antimicrob Agents 2008, 31(4):345-351.

9. Mouton JW, den Hollander JG: Killing of Pseudomonas aeruginosa during continuous and intermittent infusion of ceftazidime in an in vitro pharmacokinetic model. Antimicrob Agents Chemother 1994, 38(5):931-936.

10. Alou L, Aguilar L, Sevillano D, Giménez MJ, Echeverría O, Gómez-Lus ML, Prieto J: Is there a pharmacodynamic need for the use of continuous versus intermittent infusion with ceftazidime against Pseudomonas aeruginosa: An in vitro pharmacodynamic model. J Antimicrob Chemother 2005, 55(2):209-213.

11. Lipman J, Gomersall CD, Gin T, Joynt GM, Young RJ: Continuous infusion ceftazidime in intensive care: a randomized controlled trial. J Antimicrob Chemother 1999, 43(2):309-311.

12. Jaruratanasirikul S, Sriwiriyajan S, Punyo J: Comparison of the pharmacodynamics of meropenem in patients with ventilator-associated pneumonia following administration by 3-hour infusion or bolus injection. Antimicrob Agents Chemother 2005, 49(4):1337-1339.

13. De Jongh R, Hens R, Basma V, Mouton JW, Tulkens PM, Carryn S: Continuous versus II of temocillin, a directed spectrum penicillin for intensive care patients with nosocomial pneumonia: stability, compatibility, population pharmacokinetic studies and breakpoint selection. J Antimicrob Chemother 2008, 61(2):382-388.

14. Bulitta JB, Duffull SB, Kinzig-Schippers M, Holzgrabe U, Stephan U, Drusano GL, Sörgel F: Systematic comparison of the population pharmacokinetics and pharmacodynamics of piperacillin in cystic fibrosis patients and healthy volunteers. Antimicrob Agents Chemother 2007, 51(7):2497-2507.

15. Roberts JA, Kirkpatrick CM, Roberts MS, Robertson TA, Dalley AJ, Lipman J: Meropenem dosing in critically ill patients with sepsis and without renal dysfunction: intermittent bolus versus continuous administration? Monte Carlo dosing simulations and subcutaneous tissue distribution. J Antimicrob Chemother 2009, 64(1):142-150.

16. Rafati MR, Rouini MR, Mojtahedzadeh M, Najafi A, Tavakoli H, Gholami K, Fazeli MR: Clinical efficacy of continuous infusion of piperacillin compared with intermittent dosing in septic critically ill patients. Int $J$ Antimicrob Agents 2006, 28(2):122-127.

17. Van Zanten AR, Oudijk M, Nohlmans-Paulssen MK, van der Meer YG, Girbes $\mathrm{AR}$, Polderman $\mathrm{KH}$ : Continuous vs. intermittent cefotaxime administration in patients with chronic obstructive pulmonary disease and respiratory tract infections: pharmacokinetics/pharmacodynamics, bacterial susceptibility and clinical efficacy. Br J Clin Pharmacol 2007, 63(1):100-109.

18. Mariat C, Venet $C$, Jehl F, Mwewa S, Lazarevic V, Diconne E, Fonsale N, Carricajo A, Guyomarc'h S, Vermesch R, Aubert G, Bidault R, Bertrand JC, Zeni F: Continuous infusion of ceftazidime in critically ill patients undergoing continuous venovenous hemodiafiltration: pharmacokinetic evaluation and dose recommendation. Crit Care 2006, 10(1):R26.

19. Udy AA, Putt MT, Shanmugathasan S, Roberts JA, Lipman J: Augmented renal clearance in the Intensive Care Unit: an illustrative case series. Int J Antimicrob Agents 2010, 35(6):606-608.

20. Roberts JA, Lipman J: Antibacterial dosing in intensive care: pharmacokinetics, degree of disease and pharmacodynamics of sepsis. Clin Pharmacokinet 2006, 45(8):755-773.

21. Roosendaal R, Bakker-Woudenberg IA, Van den Berghe-Van Raffe M, den Berg JC Vink-Van, Michel BM: Impact of the dosage schedule on the efficacy of ceftazidime, gentamicin and ciprofloxacin in Klebsiella pneumoniae pneumonia and septicemia in leukopenic rats. Eur J Clin Microbiol Infect Dis 1989, 8:878-887.

22. Roosendaal $R$, Bakker-Woudenberg IA, van den Berghe-van Raffe M, Miche MF: Continuous versus intermittent administration of ceftazidime in experimental Klebsiella pneumoniae pneumonia in normal and leukopenic rats. Antimicrob Agents Chemother 1986, 30:403-408

23. Roosendaal R, Bakker-Woudenberg IA, van den Berg JC, Michel MF: Therapeutic efficacy of continuous versus intermittent administration of ceftazidime in an experimental Klebsiella pneumoniae pneumonia in rats. J Infect Dis 1985, 152:373-378.

24. Roosendaal R, Bakker-Woudenberg IA: Impact of the antibiotic dosage schedule on efficacy in experimental lung infections. Scand J Infect Dis 1990, 74:155-162.

25. Angus BJ, Smith MD, Suputtamongkol Y, Mattie H, Walsh AL, Wuthiekanun V, Chaowagul W, White NJ: Pharmacokinetic-pharmacodynamic evaluation of ceftazidime continuous infusion vs intermittent bolus injection in septicaemic melioidosis. Br J Clin Pharmacol 2000, 50:184-191.

26. Buijk SL, Gyssens IC, Mouton JW, Van Vliet A, Verbrugh HA, Bruining HA Pharmacokinetics of ceftazidime in serum and peritoneal exudate during continuous versus intermittent administration to patients with severe intra-abdominal infections. J Antimicrob Chemother 2002, 49 (1):121-128

27. Benko AS, Cappelletty DM, Kruse JA, Rybak MJ: Continuous infusion versus intermittent administration of ceftazidime in critically ill patients with suspected gram-negative infections. Antimicrob Agents Chemother 1996, 40:691-695. 
28. Hanes SD, Wood GC, Herring V, Croce MA, Fabian TC, Pritchard E, Boucher BA: Intermittent and continuous ceftazidime infusion for critically ill trauma patients. Am J Surg 2000, 179(6):436-440.

29. Boselli $E$, Breilh D, Rimmele $T$, et al: Plasma and lung concentrations of ceftazidime administered in continuous infusion to critically ill patients with severe nosocomial pneumonia. Intensive Care Med 2004 30:989-991

30. Jaruratanasirikul S, Sriwiriyajan S, Ingviya N: Continuous infusion versus intermittent administration of cefepime in patients with Gram-negative bacilli bacteraemia. J Pharm Pharmacol 2002, 54:1693-1696.

31. Boselli E, Breilh D, Duflo F, et al: Steady-state plasma and intrapulmonary concentrations of cefepime administered in continuous infusion in critically ill patients with severe nosocomial pneumonia. Crit Care Med 2003, 31:2102-2106.

32. Li C, Kuti JL, Nightingale CH, Mansfield DL, Dana A, Nicolau DP: Population pharmacokinetics and pharmacodynamics of piperacillin/tazobactam in patients with complicated intra-abdominal infection. J Antimicrob Chemother 2005, 56(2):388-395

33. Roberts JA, Roberts MS, Dalley A, Cross SE, Lipman J: Exposure and predicted antimicrobial efficacy in critically ill patients: piperacillin. In The Society of Hospital Pharmacists of Australia: Queensland Branch Conference; 21-22 October 2006. Brisbane, Australia: SHPA; 2006.

34. Roberts JA, Webb S, Paterson D, Ho KM, Lipman J: A systematic review on clinical benefits of continuous administration of beta-lactam antibiotics. Crit Care Med 2009, 37(6):2071-2078.

35. Roberts JA, Boots R, Rickard CM, Thomas P, Quinn J, Roberts DM, Richards B, Lipman J: Is continuous infusion ceftriaxone better than once-a-day dosing in intensive care? A randomized controlled pilot study. J Antimicrob Chemother 2007, 59(2):285-291.

36. Bodey GP, Ketchel SJ, Rodriguez V: A randomized study of carbenicillin plus cefamandole or tobramycin in the treatment of febrile episodes in cancer patients. Am J Med 1979, 67(4):608-616.

37. Lagast H, Meunier-Carpentier F, Klastersky J: Treatment of gram-negative bacillary septicemia with cefoperazone. Eur J Clin Microbiol 1983 2(6):554-558.

38. Nicolau DP, McNabb J, Lacy MK, Quintiliani R, Nightingale CH: Continuous versus intermittent administration of ceftazidime in intensive care unit patients with nosocomial pneumonia. Int J Antimicrob Agents 2001, 17 (6):497-504.

39. Pedebosca S, Dubau B, Frappier S, Hernandez V, Veyssières D, Winnock S, Pometan JP: Comparison of 2 administration protocols (continuous or discontinuous) of a time-dependent antibiotic, Tazocin. Pathol Biol 2001, 49:540-547.

40. Buck C, Bertram N, Ackermann T, Sauerbruch T, Derendorf H, Paar WD: Pharmacokinetics of piperacillin-tazobactam: Intermittent dosing versus continuous infusion. Int J Antimicrob Agents 2005, 25:62-67.

41. Georges B, Conil JM, Cougot P, Decun JF, Archambaud M, Seguin T, Chabanon G, Virenque C, Houin G, Saivin S: Cefepime in critically ill patients: Continuous infusion vs. an intermittent dosing regimen. Int J Clin Pharmacol Ther 2005, 43:360-369.

42. Lau WK, Mercer D, Itani KM, Nicolau DP, Kuti JL, Mansfield D, Dana A: Randomized, open-label, comparative study of piperacillin-tazobactam administered by continuous infusion versus intermittent infusion for treatment of hospitalized patients with complicated intra-abdominal infection. Antimicrob Agents Chemother 2006, 50:3556-3561.

43. Kojika M, Sato N, Hakozaki M, Suzuki Y, Takahasi G, Endo S, Suzuki K, Wakabayasi G: A preliminary study of the administration of carbapenem antibiotics in sepsis patients on the basis of the administration time. Jpn $J$ Antibiot 2005, 58(5):452-457.

44. Sakka SG, Glauner AK, Bulitta JB, Kinzig-Schippers M, Pfister W, Drusano GL, Sörgel F: Population pharmacokinetics and pharmacodynamics of continuous versus short-term infusion of imipenem-cilastatin in critically ill patients in a randomized, controlled trial. Antimicrob Agents Chemother 2007, 51:3304-3310.

45. Walton AL, Howden BP, Grayson LM, Korman TM: Continuous-infusion penicillin home-based therapy for serious infections due to penicillin-susceptible pathogens. Int J Antimicrob Agents 2007, 29 (5):544-548

46. Howden BP, Richards MJ: The efficacy of continuous infusion flucloxacillin in home therapy for serious staphylococcal infections and cellulitis. J Antimicrob Chemother 2001, 48(2):311-314.
47. Leder K, Turnidge JD, Korman TM, Grayson ML: The clinical efficacy of continuous-infusion flucloxacillin in serious staphylococcal sepsis. J Antimicrob Chemother 1999, 43(1):113-118.

48. Hughes DW, Frei CR, Maxwell PR, Green K, Patterson JE, Crawford GE, Lewis $\mathrm{JS}$ : Continuous versus intermittent infusion of oxacillin for treatment of infective endocarditis caused by methicillin-susceptible Staphylococcus aureus. Antimicrob Agents Chemother 2009, 53(5):2014-2019.

49. Grant EM, Kuti JL, Nicolau DP, Nightingale C, Quintiliani R: Clinical efficacy and pharmacoeconomics of a continuous-infusion piperacillintazobactam program in a large community teaching hospital. Pharmacotherapy 2002, 22(4):471-483.

50. Lodise TP Jr, Lomaestro B, Drusano GL: Piperacillin-tazobactam for Pseudomonas aeruginosa infection: clinical implications of an extendedinfusion dosing strategy. Clin Infect Dis 2007, 44(3):357-363.

51. Lorente L, Jiménez A, Martín MM, Iribarren JL, Jiménez JJ, Mora ML: Clinical cure of ventilator-associated pneumonia treated with piperacillin/ tazobactam administered by continuous or intermittent infusion. Int $J$ Antimicrob Agents 2009, 33(5):464-468.

52. Lorente L, Jiménez A, Palmero S, Jiménez JJ, Iribarren JL, Santana M, Martín $\mathrm{MM}$, Mora ML: Comparison of clinical cure rates in adults with ventilatorassociated pneumonia treated with intravenous ceftazidime administered by continuous or intermittent infusion: a retrospective, nonrandomized, open-label, historical chart review. Clin Ther 2007, 29(11):2433-2439.

53. Lorente L, Lorenzo L, Martín MM, Jiménez A, Mora ML: Meropenem by continuous versus intermittent infusion in ventilator-associated pneumonia due to gram-negative bacilli. Ann Pharmacother 2006, 40(2):219-223.

54. Daikos GL, Markogiannakis A: Carbapenemase-producing Klebsiella pneumoniae: (when) might we still consider treating with carbapenems? Clin Microbiol Infect 2011, 17(8):1135-1141.

55. McNabb JJ, Nightingale CH, Quintiliani R, Nicolau DP: Cost-effectiveness of ceftazidime by continuous infusion versus intermittent infusion for nosocomial pneumonia. Pharmacotherapy 2001, 21(5):549-555.

56. Mouton JW, Vinks AA: Continuous infusion of beta-lactams. Curr Opin Crit Care 2007, 13(5):598-606

57. Martin JH, Fay MF, Udy A, Roberts J, Kirkpatrick C, Ungerer J, Lipman J: Pitfalls of using estimations of glomerular filtration rate in an intensive care population. Intern Med J 2011, 41(7):537-543.

58. Taccone FS, Laterre PF, Dugernier T, Spapen H, Delattre I, Wittebole X, De Backer D, Layeux B, Wallemacq P, Vincent $J$, Jacobs F: Insufficient $\beta$-lactam concentrations in the early phase of severe sepsis and septic shock. Crit Care 2010, 14(4):R126.

59. Viaene E, Chanteux $H$, Servais $H$, Mingeot-Leclercq MP, Tulkens PM: Comparative stability studies of antipseudomonal beta-lactams for potential administration through portable elastomeric pumps (home therapy for cystic fibrosis patients) and motor-operated syringes (intensive care units). Antimicrob Agents Chemother 2002, 46(8):2327-2332.

60. Vinks AA, Touw DJ, van Rossen RC, Heijerman HG, Bakker W: Stability of aztreonam in a portable pump reservoir used for home intravenous antibiotic treatment (HIVAT). Pharm World Sci 1996, 18(2):74-77.

61. Servais H, Tulkens PM: Stability and compatibility of ceftazidime administered by continuous infusion to intensive care patients. Antimicrob Agents Chemother 2001, 45(9):2643-2647.

62. Baririan N, Chanteux H, Viaene E, Servais H, Tulkens PM: Stability and compatibility study of cefepime in comparison with ceftazidime for potential administration by continuous infusion under conditions pertinent to ambulatory treatment of cystic fibrosis patients and to administration in intensive care units. J Antimicrob Chemother 2003, 51 (3):651-658.

63. Berthoin K, Le Duff CS, Marchand-Brynaert J, Carryn S, Tulkens PM: Stability of meropenem and doripenem solutions for administration by continuous infusion. J Antimicrob Chemother 2010, 65(5):1073-1075

64. Trissel: Handbook on infectible drugs. 15th edition. Bethesda: America Society of Health System Pharmacists; 2009.

65. Vella-Brincat JW, Begg EJ, Gallagher K, Kirkpatrick CM, Zhang M, Frampton C, Chambers ST: Stability of benzylpenicillin during continuous home intravenous therapy. J Antimicrob Chemother 2004, 53(4):675-677.

66. Craig WA: Basic pharmacodynamics of antibacterials with clinical applications to the use of beta-lactams, glycopeptides, and linezolid. Infect Dis Clin North Am 2003, 17(3):479-501.

67. Ebert S: vivo cidal activity and pharmacokinetic parameters for vancomycin against methicillin-susceptible and -resistant $S$. aureus 
[abstract 439]. In Program and abstracts of the 27th Interscience Conference on Antimicrobial Agents and Chemotherapy (New York). Washington, DC: American Society for Microbiology; 1987:173.

68. Dudley M, Griffith D, Corcoran E, Liu C, Sorensen K, Tembe V: PK/PD indices for vancomycin treatment of susceptible (VSSA) and intermediate (VISA) S. aureus in the neutropenic murine thigh model. In Program and abstracts of the $39^{\text {th }}$ Interscience Conference on Antimicrobial Agents and Chemotherapy (San Francisco). Washington: American Society for Microbiology; 1999:49.

69. Moise-Broder PA, Forrest A, Birmingham MC, Schentag JJ: Pharmacodynamics of vancomycin and other antimicrobials in patients with Staphylococcus aureus lower respiratory tract infections. Clin Pharmacokinet 2004, 43(13):925-942.

70. Rybak M, Lomaestro B, Rotschafer JC, Moellering R Jr, Craig W, Billeter M, Dalovisio JR, Levine DP: Therapeutic monitoring of vancomycin in adult patients: a consensus review of the American Society of Health-System Pharmacists, the Infectious Diseases Society of America, and the Society of Infectious Diseases Pharmacists. Am J Health Syst Pharm 2009, 66(1):82-98.

71. Wysocki M, Delatour F, Faurisson F, Rauss A, Pean Y, Misset B, Thomas F, Timsit JF, Similowski T, Mentec H, Mier L, Dreyfuss D: Continuous versus intermittent infusion of vancomycin in severe Staphylococcal infections: prospective multicenter randomized study. Antimicrob Agents Chemother 2001, 45(9):2460-2467.

72. Vuagnat A, Stern R, Lotthe A, Schuhmacher $H$, Duong M, Hoffmeyer $P$, Bernard L: High dose vancomycin for osteomyelitis: continuous vs. intermittent infusion. J Clin Pharm Ther 2004, 29(4):351-357.

73. Di Filippo A, De Gaudio AR, Novelli A, Paternostro E, Pelagatti C, Livi P, Novelli GP: Continuous infusion of vancomycin in methicillin-resistant staphylococcus infection. Chemotherapy 1998, 44(1):63-68.

74. Rello J, Sole-Violan J, Sa-Borges M, Garnacho-Montero J, Muñoz E, Sirgo G, Olona M, Diaz E: Pneumonia caused by oxacillin-resistant Staphylococcus aureus treated with glycopeptides. Crit Care Med 2005, 33(9):1983-1987.

75. Ingram PR, Lye DC, Fisher DA, Goh WP, Tam VH: Nephrotoxicity of continuous versus intermittent infusion of vancomycin in outpatient parenteral antimicrobial therapy. Int J Antimicrob Agents 2009, 34(6):570-574.

76. Hutschala D, Kinstner C, Skhirdladze K, Thalhammer F, Müller M, Tschernko E: Influence of vancomycin on renal function in critically ill patients after cardiac surgery: continuous versus intermittent infusion. Anesthesiology 2009, 111(2):356-365.

77. Byl B, Jacobs F, Wallemacq P, Rossi C, de Francquen P, Cappello M, Leal T, Thys JP: Vancomycin penetration of uninfected pleural fluid exudate after continuous or intermittent infusion. Antimicrob Agents Chemother 2003, 47(6):2015-2017.

78. Cataldo MA, Tacconelli E, Grilli E, Pea F, Petrosillo N: Continuous versus intermittent infusion of vancomycin for the treatment of Gram-positive infections: systematic review and meta-analysis. J Antimicrob Chemother 2012, 67(1):17-24.

79. Spapen HD, Janssen van Doorn K, Diltoer M, Verbrugghe W, Jacobs R, Dobbeleir N, Honoré PM, Jorens PG: Retrospective evaluation of possible renal toxicity associated with continuous infusion of vancomycin in critically ill patients. Ann Intensive Care 2011, 19(1):1-26.

80. Gupta A, Biyani M, Khaira A: Vancomycin nephrotoxicity: myths and facts. Neth J Med 2011, 69(9):379-383.

81. Liu C, Bayer A, Cosgrove SE, Daum RS, Fridkin SK, Gorwitz RJ, Kaplan SL, Karchmer AW, Levine DP, Murray BE, Rybak JM, Talan DA, Chambers HF: Clinical practice guidelines by the Infectious Diseases Society of America for the treatment of methicillin-resistant Staphylococcus aureus infections in adults and children. Clin Infect Dis 2011, 52(3):18-55.

82. Ingram PR, Lye DC, Tambyah PA, Goh WP, Tam VH, Fisher DA: Risk factors for nephrotoxicity associated with continuous vancomycin infusion in outpatient parenteral antibiotic therapy. J Antimicrob Chemother 2008, 62 (1):168-171.

83. Jeurissen A, Sluyts I, Rutsaert R: A higher dose of vancomycin in continuous infusion is needed in critically ill patients. Int J Antimicrob Agents 2011, 37(1):75-77.

doi:10.1186/2110-5820-2-22

Cite this article as: Van Herendael et al:: Continuous infusion of antibiotics in the critically ill: The new holy grail for beta-lactams and vancomycin?. Annals of Intensive Care 2012 2:22.

\section{Submit your manuscript to a SpringerOpen ${ }^{\circ}$ journal and benefit from:}

- Convenient online submission

- Rigorous peer review

- Immediate publication on acceptance

- Open access: articles freely available online

- High visibility within the field

- Retaining the copyright to your article

Submit your next manuscript at $>$ springeropen.com 